\title{
CELL THERAPY FOR MEDICATION-RELATED OSTEONECROSIS OF THE JAW: UPDATE ON TREATMENT STRATEGIES
}

\author{
N. Kaibuchi ${ }^{1,2}$, T. Iwata ${ }^{1,3, *}$, T. Okamoto ${ }^{1}$, Y. Kawase-Koga ${ }^{1}$ and M. Yamato ${ }^{2}$ \\ ${ }^{1}$ Department of Oral and Maxillofacial Surgery, Tokyo Women's Medical University School of Medicine, \\ 8-1 Kawada-cho, Shinjuku-ku, Tokyo 162-8666, Japan \\ ${ }^{2}$ Institute of Advanced Biomedical Engineering and Science, Tokyo Women's Medical University (TWIns), \\ 8-1 Kawada-cho, Shinjuku-ku, Tokyo 162-8666, Japan \\ ${ }^{3}$ Department of Periodontology, Graduate School of Medical and Dental Sciences, Tokyo Medical and \\ Dental University (TMDU), 1-5-45 Yushima, Bunkyo-ku, Tokyo 113-8510, Japan
}

\begin{abstract}
Despite extensive research since the first report of medication-related osteonecrosis of the jaw (MRONJ) in 2003, the optimal treatment and preventive modalities for the condition are not clear. Therefore, its management has been a concern in dentistry, oral and maxillofacial surgery, as well as departments involved in the treatment of cancers and/or bone diseases worldwide. Several cases of MRONJ could not be cured by conventional treatment strategies, as per the recommendations in various position papers. Therefore, a number of studies, including randomized controlled trials, have been conducted to examine the efficacy of novel therapies. However, no definite treatment modality has been determined. Several types of cell therapies have been documented. 10 animal studies and 5 case reports have been documented, in which autologous transplantation of cells has been carried out in MRONJ patients. Although these reports showed the efficacy of cell therapy, they were not large-scale, statistically accurate clinical studies; hence, the efficacy of cell therapy for this condition is not certain. However, the efficacy of MRONJ treatment using mesenchymal stromal cell (MSC) sheets has been investigated since 2013. This has been confirmed through various experiments in which MSC sheets were transplanted into model rats and beagle dogs exhibiting MRONJ-like lesions. Based on these results, a clinical study of MRONJ treatment using periodontal ligament-derived MSC sheets is being currently planned.
\end{abstract}

Keywords: Bisphosphonate, anti-resorptive agents, anti-receptor activator of NFk $\beta$ ligand antibody, denosumab, anti-cancer agents, osteonecrosis of the jaw, cell therapy, cytotherapy, regenerative therapy, cell sheet.

*Address for correspondence: Takanori Iwata, D.D.S., Ph.D., Professor and Chair, Department of Periodontology, Graduate School of Medical and Dental Sciences, Tokyo Medical and Dental University (TMDU), 1-5-45 Yushima, Bunkyo-ku, Tokyo 113-8510, Japan.

Telephone number: +81358035488 Fax number: +81358030196 Email: iwata.peri@tmd.ac.jp

Copyright policy: This article is distributed in accordance with Creative Commons Attribution Licence (http://creativecommons.org/licenses/by-sa/4.0/).

\section{Overview of medication-related osteonecrosis of the jaw}

The first case of medication-related osteonecrosis of the jaw (MRONJ) was associated with bisphosphonate and reported by Marx in 2003 (Marx, 2003). Since then, cases have been increasing worldwide. MRONJ has been defined by the American Association of Oral and Maxillofacial Surgeons as

1. current or previous treatment with antiresorptive agents such as nitrogen-containing bisphosphonates (NBPs), anti-receptor activator of NFk $\beta$ ligand (RANKL) antibodies (denosumab; Dmab), or anti-angiogenic agents.

2. bone exposure or bone that can be probed through a fistula in the oral and maxillofacial region presenting for more than 8 weeks.

3. no history of radiation therapy or certain metastatic disease to the jaws. It is divided into three stages according to the symptoms (Table 1 ). NBPs inhibit the activity of osteoclasts and are used to prevent and treat diseases such as osteoporosis, bone metastases of cancer, and multiple myeloma. The incidence of MRONJ in patients receiving 
intravenous NBPs is approximately $1 \%$ (Coleman et al., 2011) and that in patients receiving oral NBPs is approximately $0.1 \%$, which increases to $0.21 \%$ after more than 4 years of oral NBP administration (Lo et al., 2010). Dmab acts in a similar way to NBPs by inhibiting RANKL (Pageau et al., 2009). Though it was speculated that Dmab cannot cause MRONJ, it actually causes MRONJ at the same rate as NBPs (Ruggiero et al., 2014). The etiology of MRONJ is still not clear, despite extensive research. So far, over-suppression of bone metabolism, inhibition of angiogenesis, effects on immune function, mucosal irritation, oral bacterial infection, and surgical invasion of the jawbone have been implicated in the etiology of MRONJ (Khan et al., 2014; Ruggiero et al., 2014). Moreover, some rare cases of MRONJ have been caused by the use of anti-angiogenic agents such as multi-targeted receptor tyrosine kinase inhibitors (sunitinib) and vascular endothelial growth factor A inhibitors (bevacizumab) (Fleissig et al., 2012; Maluf et al., 2019).

\section{Conventional and novel treatment strategies for MRONJ}

The treatment of MRONJ is categorized according to stage, as per the recommendations of a position paper (Table 1) (Ruggiero et al., 2014). Conservative treatment is recommended for mild cases, such as Stages 1 and 2, and surgical treatment is recommended for more severe cases, such as Stage 3. However, several cases cannot be treated using conventional treatment strategies.

A systematic review reported that total healing rates for conservative treatments were $33 \%$ in Stage

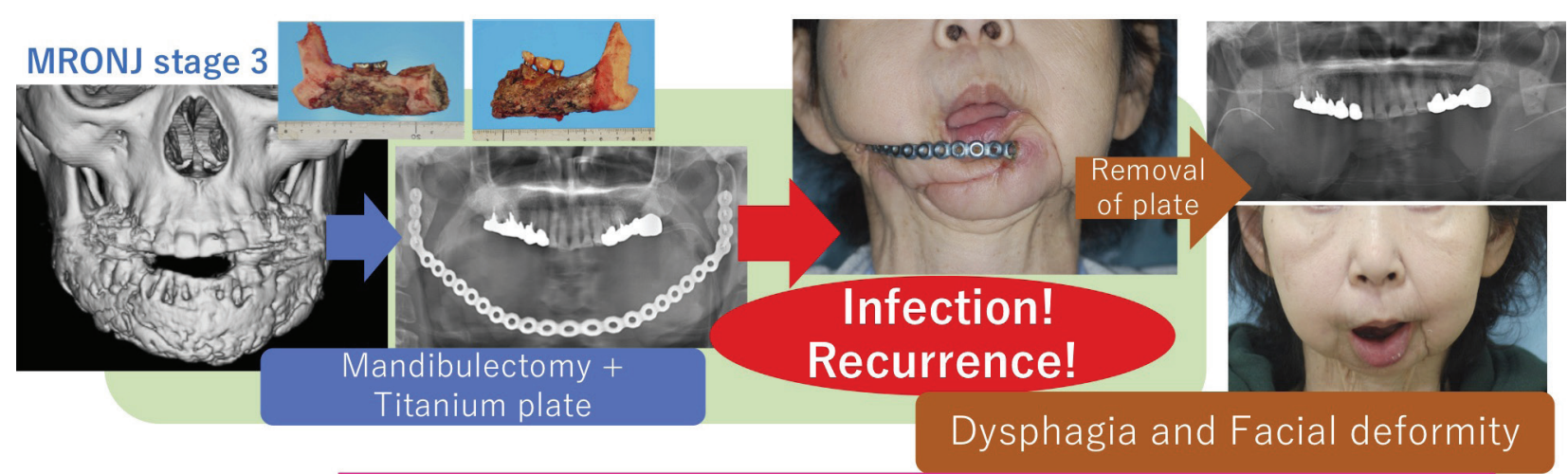

Loss of a significant portion of the mandible may precipitate the need for permanent tracheotomy due to chronic aspiration!

Fig. 1. Illustration of MRONJ in a 64-year-old female patient. She was administered zoledronate and denosumab for breast cancer. MRONJ developed around the mandibular dental implants and worsened to Stage 3; subtotal mandibulectomy was performed. As reconstructive surgery was difficult, Ti-plate reconstruction of the mandible was performed. However, the Ti-plate became infected and had to be removed. In such cases, permanent tracheotomy may be necessary.

Table 1. Treatment strategies for MRONJ according to stage. MRONJ: medication-related osteonecrosis of the jaw (Ruggiero et al., 2014).

\begin{tabular}{|l|l|l|}
\hline \multicolumn{1}{|c|}{ MRONJ staging } & \multicolumn{1}{c|}{ Treatment strategies } \\
\hline Stage 1 & $\begin{array}{l}\text { Exposed and necrotic bone, or fistulae that probes } \\
\text { to bone, in patients who are asymptomatic and have } \\
\text { no evidence of infection. }\end{array}$ & $\begin{array}{l}\bullet \text { Antibacterial mouth rinse. } \\
\text { - Clinical follow-up on a quarterly basis. } \\
\text { Patient education and review of indications for } \\
\text { continued bisphosphonate therapy. }\end{array}$ \\
\hline Stage 2 & $\begin{array}{l}\text { Exposed and necrotic bone, or fistulae that probes } \\
\text { to bone, associated with infection as evidenced by } \\
\text { pain and erythema in the region of the exposed } \\
\text { bone with or without purulent drainage. }\end{array}$ & $\begin{array}{l}\bullet \text { Symptomatic treatment with oral antibiotics. } \\
\text { - Oral antibacterial mouth rinse. } \\
\bullet \text { Pain control. } \\
\bullet \text { Debridement to relieve soft tissue irritation and } \\
\text { infection control. }\end{array}$ \\
\hline Stage 3 3 & $\begin{array}{l}\text { Exposed and necrotic bone or a fistula that probes } \\
\text { to bone in patients with pain, infection, and one or } \\
\text { more of the following: exposed and necrotic bone } \\
\text { extending beyond the region of alveolar bone, } \\
\text { resulting in pathological fracture, extra-oral fistula, } \\
\text { oral antral/oral nasal communication, or osteolysis } \\
\text { extending to the inferior border of the mandible of } \\
\text { sinus floor. }\end{array}$ & $\begin{array}{l}\bullet \text { Antibacterial mouth rinse. } \\
\text { - Antibiotic therapy and pain control. } \\
\text { Surgical debridement/resection for longer term } \\
\text { palliation of infection and pain. }\end{array}$ \\
\hline
\end{tabular}


1 and $24 \%$ in Stage 2 (Rupel et al., 2014). Hence, several studies reported that surgical treatment is significantly superior to conservative treatment (Fliefel et al., 2015; Khan et al., 2014; Rupel et al., 2014). In particular, Hayashida et al. (2020) proposed that surgical treatment should be considered as the first line of treatment for MRONJ, regardless of the stage. However, the cure rate of surgical treatment for MRONJ ranges from $60 \%$ to $80 \%$ even in reports of high cure rate, and cases of postoperative recurrence are not uncommon. A multicenter retrospective study reported that half of the surgically treated cases of MRONJ, caused by high-dose NBPs or Dmab for cancer, did not show a complete cure (Hayashida et al., 2017). In addition, such surgeries involve the removal of a large portion of the jawbone. This significantly affects swallowing, speech, facial morphology, and esthetics of the patient, further impairing the patient's quality of life. Furthermore, considerable difficulties are encountered in reconstructive surgery due to the effects of NBPs or Dmab on all bones of the body (Fig. 1). In fact, a case was reported describing the development of MRONJ in the mandible, reconstructed using fibular tissue (Gryseleyn et al., 2016). Recently, Hokugo et al. (2019) reported that non-NBPs (etidronate) can selectively inhibit the effects of NBPs on the bones. The working hypothesis was that this would counteract the difficulties in reconstructive surgery caused by NBPs. Previous studies have investigated novel approaches for MRONJ treatment, including hyperbaric oxygen therapy (Freiberger et al., 2012), platelet-rich plasma
(Adornato et al., 2007; Curi et al., 2011), low-intensity laser irradiation (Favia et al., 2018; Scoletta et al., 2010), parathyroid hormones (Cheung and Seeman, 2010; Sim et al., 2020), bone morphogenetic proteins (Park et al., 2017), plasma rich in growth factors (Mozzati et al., 2012), pentoxifylline and tocopherol (HeifetzLi et al., 2019), and cell therapy (Tables 2 and 3). Of these, no treatment modality is widely accepted (De Souza Tolentino et al., 2019). Sim et al. (2020) demonstrated the promising therapeutic effects of teriparatide, which is a parathyroid hormone, against MRONJ in a randomized controlled clinical trial. However, the use of teriparatide in MRONJ patients is challenging, because its administration is difficult in cancer patients, and the duration of administration is limited to 24 months. In addition, the need for discontinuation of NBPs or Dmab during the treatment of MRONJ is controversial. Hinson et al. (2015) and Magopoulos et al. (2007) reported that treatment outcomes with the discontinuation of NBPs or Dmab are better than those without. However, a risk for exacerbation of the target disease by such drug holidays is inevitable.

\section{Cell therapy for MRONJ}

To date, 10 studies with animal models and 5 studies with humans in clinical practice have been reported on cell therapy for MRONJ, including studies using cell sheets (Table 3). 4 studies using bone marrowderived mesenchymal stem (stromal) cells (MSCs),

Table 2. Novel treatment modalities for MRONJ. HBO: hyperbaric oxygen therapy; RCT: randomized controlled trial; BMP: bone morphogenetic protein; L-PRF: leukocyte-rich and platelet-rich fibrin.

\begin{tabular}{|c|c|c|c|c|}
\hline $\begin{array}{c}\text { Novel } \\
\text { treatments }\end{array}$ & Reference & $\begin{array}{c}\text { Study } \\
\text { design }\end{array}$ & Patient \# & Outcomes \\
\hline $\begin{array}{c}\text { Hyperbaric } \\
\text { oxygen } \\
\text { therapy }\end{array}$ & $\begin{array}{c}\text { Freiberger } \\
\text { JJ } \text { et al., 2012 }\end{array}$ & RCT & 25 & $68 \%$ of HBO-treated patients and 38.1\% of controls improved \\
$(p=0.43)$.
\end{tabular}


3 studies using adipose-derived stem (stromal) cells (ASCs), 1 using cells from stromal vascular fraction (SVF), 1 using cells from peripheral blood, and 1 using media from MSCs, have been reported in animal models. As SVF cells contain ASCs, 9 of the 10 studies examined the therapeutic effects of MSCs in MRONJ. 1 study analyzed xenografts with human-derived cells into rabbits (Zang et al., 2019). Supernatants of human bone marrow-derived MSCs, instead of cell transplantation, have been used in an animal study (Ogata et al., 2015). With regard to scaffolds for cell transplantation, hydroxyapatite or beta-tricalcium phosphate have been used in 2 animal studies (Rodríguez-Lozano et al., 2020; Zang et al., 2019). No transplanted cell was induced to differentiate artificially prior to transplantation. All animal studies showed that cell therapies are effective in the treatment or prevention of MRONJ-like conditions. Few reports of cell therapy for MRONJ in clinical practice have been documented with only 5 papers on 12 patients (Table 3). All papers were case reports, and none included statistical analysis. In addition, the cells used in 4 papers were not cultured, and local autologous transplantation was performed in the patients. In 1 study, autologous transplantation of MSCs cultured in osteogenic differentiation medium was performed in 2 patients. The cells used in clinical practice were bone marrow-derived cells or adiposederived cells containing MSCs. Thus, similar to most animal studies, all MRONJ cases were treated by cell therapy in anticipation of the effects of MSCs. Some materials or growth factors were used in conjunction

Table 3. Cell therapy for MRONJ. MSC: mesenchymal stem (stromal) cells; ASC: adipose-derived stem (stromal) cells; SVF: stromal vascular fraction; $\beta$-TCP: beta tricalcium phosphate; HA: hydroxyapatite; PGA: polyglycolic acid; PRP: platelet-rich plasma; PRF: plasma rich in growth factors; DBBM: deproteinized bovine bone mineral; DBM: demineralized bone matrix.

\section{Animal studies}

\begin{tabular}{|c|c|c|c|c|c|c|c|c|}
\hline Reference & Country & Source of cells & $\begin{array}{l}\text { Graft } \\
\text { type }\end{array}$ & Culture & Induction & Route & $\begin{array}{c}\text { Other } \\
\text { materials }\end{array}$ & Animals \\
\hline $\begin{array}{l}\text { Rodríguez- } \\
\text { Lozano FJ et } \\
\text { al., } 2020\end{array}$ & Spain & $\begin{array}{l}\text { Bone marrow- } \\
\text { derived MSC }\end{array}$ & Allograft & Yes & No & Local & $\beta$-ТCP & Rat \\
\hline $\begin{array}{c}\text { Kuroshima S et } \\
\text { al., } 2019\end{array}$ & Japan & $\begin{array}{l}\text { Peripheral blood } \\
\text { mononuclear cells }\end{array}$ & Autograft & Yes & No & Intravenous & None & Mouse \\
\hline $\begin{array}{c}\text { Zang X et al., } \\
2019\end{array}$ & China & Human ASC & Xenograft & Yes & No & Local & Coral HA & Rabbit \\
\hline $\begin{array}{c}\text { Kaibuchi N et } \\
\text { al., } 2019\end{array}$ & Japan & ASC & Allograft & Yes & No & Local & PGA sheet & Beagle \\
\hline $\begin{array}{c}\text { Kuroshima S et } \\
\text { al., } 2018\end{array}$ & Japan & SVF cells & Allograft & No & No & Intravenous & None & Mouse \\
\hline $\begin{array}{c}\text { Kaibuchi N et } \\
\text { al., } 2016\end{array}$ & Japan & $\begin{array}{l}\text { Bone marrow- } \\
\text { derived MSC }\end{array}$ & Allograft & Yes & No & Local & None & Rat \\
\hline $\begin{array}{c}\text { Ogata Ket al., } \\
2015\end{array}$ & Japan & $\begin{array}{l}\text { Media from human } \\
\text { MSC }\end{array}$ & & & & Intravenous & None & Rat \\
\hline $\begin{array}{l}\text { Barba-Recreo } \\
\text { P et al., } 2015\end{array}$ & Spain & ASC & Allograft & Yes & No & Local & PRP & Rat \\
\hline
\end{tabular}

\section{Clinical practice}

\begin{tabular}{|c|c|c|c|c|c|c|c|c|c|}
\hline Reference & Country & $\begin{array}{c}\text { Source of } \\
\text { cells }\end{array}$ & $\begin{array}{c}\text { Graft } \\
\text { type }\end{array}$ & Culture & Induction & Route & $\begin{array}{c}\text { Other } \\
\text { materials }\end{array}$ & $\begin{array}{c}\text { Study } \\
\text { design }\end{array}$ & patient \# \\
\hline $\begin{array}{c}\text { Bouland C } \text { et } \\
\text { al., 2020 }\end{array}$ & Belgium & SVF & Autograft & No & No & Local & L-PRF & $\begin{array}{c}\text { Case } \\
\text { report }\end{array}$ & 2 \\
\hline $\begin{array}{c}\text { De Santis GC } \\
\text { et al., 2020 }\end{array}$ & Brazil & $\begin{array}{c}\text { Bone } \\
\text { marrow } \\
\text { derived MSC }\end{array}$ & Autograft & Yes & Yes & Local & DBBM & $\begin{array}{c}\text { Case } \\
\text { report }\end{array}$ & 2 \\
\hline $\begin{array}{c}\text { Voss PJ } \text { et al., } \\
2017\end{array}$ & Germany & $\begin{array}{c}\text { Bone } \\
\text { marrow } \\
\text { stem cells }\end{array}$ & Autograft & No & No & Local & $\begin{array}{c}\text { Collagen } \\
\text { membrane }\end{array}$ & $\begin{array}{c}\text { Case } \\
\text { report }\end{array}$ & 6 \\
\hline $\begin{array}{c}\text { Gonzálvez- } \\
\text { García M } \text { et al., } \\
2013\end{array}$ & Spain & $\begin{array}{c}\text { Bone } \\
\text { marrow } \\
\text { stem cells }\end{array}$ & Autograft & No & No & Local & $\begin{array}{c}\text { PRP, } \beta \text {-TCP } \\
\text { and DBM }\end{array}$ & $\begin{array}{c}\text { Case } \\
\text { report }\end{array}$ & 1 \\
\hline $\begin{array}{c}\text { Cella L } \text { et al., } \\
2011\end{array}$ & Italy & $\begin{array}{c}\text { Bone } \\
\text { marrow } \\
\text { stem cell }\end{array}$ & Autograft & No & No & Local & $\begin{array}{c}\text { Gelatin } \\
\text { Spong }\end{array}$ & $\begin{array}{c}\text { Case } \\
\text { report }\end{array}$ & 1 \\
\hline
\end{tabular}


with cell transplantation. In all cases, significant improvement in MRONJ was reported.

\section{Cell sheet engineering for MRONJ}

Cell sheet engineering is a technique that allows the collection of cells in sheet form by culture using temperature-responsive culture dishes. It enables the transplantation of cells that maintain the extracellular matrix. Treatments based on this technique have already proven effective in corneal dysfunction (Nishida et al., 2004), myocardial infarction (Miyahara et al., 2006), and esophageal ulcerations (Ohki et al., 2012). In dentistry, Iwata et al. (2018) conducted a clinical study in which periodontal ligament-derived MSC sheets were transplanted into 10 patients for periodontal reconstruction and observed significant improvements in radiographic bone height and various clinical findings. Since 2013 , analysis of the use of cell sheet engineering as the optimal method of cell transplantation in the treatment of MRONJ has been carried out (Kaibuchi et al., 2016; Kaibuchi et al., 2019). In 1 study, after the administration of zoledronate and dexamethasone in SpragueDawley (SD) rats, the maxillary first molars were extracted to establish a rat model with MRONJlike lesions. Multipotent MSC sheets derived from the bone marrow of enhanced green fluorescent protein (EGFP)-positive SD rats were allogeneically transplanted in rat models with MRONJ-like lesions to examine their efficacy in the treatment of MRONJ and cellular behavior at the transplanted site. After surgical debridement, 1 MSC sheet was transplanted into an exposed bone (MSC sheet group) or no cell transplantation (control group) was carried out in the rat model. The wounds in both groups were closed. The MSC sheet group in most cases $(87.5 \%)$ showed adequate wound healing compared with the control group (20\%) $(p<0.05)$ (Fig. 2). The number of newly formed blood vessels was significantly greater at the transplanted site in the MSC sheet group than that in the control group, and osteoclasts reduced due to zoledronate administration increased in the MSC sheet group. Furthermore, some of the transplanted MSCs were positive for CD146, a marker for pericytes. These results suggested that the therapeutic effects of MSC sheets in MRONJ could be due to a combination of paracrine effects such as secretion of vascular endothelial growth factor and hepatocyte growth factor from MSCs, promotion of angiogenesis by differentiation of MSCs into pericytes, and promotion of osteoclast differentiation by RANKL secretion and osteoblast differentiation by MSCs themselves (Fig. 3) (Kaibuchi et al., 2016). In another study, after the invasion of the mandible of beagle dogs treated with zoledronate and dexamethasone, MSC sheets were transplanted in these dog models with MRONJlike lesions, and the groups with and without transplantation were compared. The control group showed MRONJ-like inflammatory findings and the presence of sequestrum and bacterial colonies, whereas the transplant group showed complete healing (Fig. 4) (Kaibuchi et al., 2019). Further research into the clinical applications of cell therapy is being conducted. The tissue used as a source of MSCs for clinical research is important. Periodontal ligamentderived MSC seem appropriate for cell therapy, and the roles of these cells have already been explored in dentistry. Conducting a clinical study of MRONJ treatment using periodontal ligament-derived MSC sheets is planned.

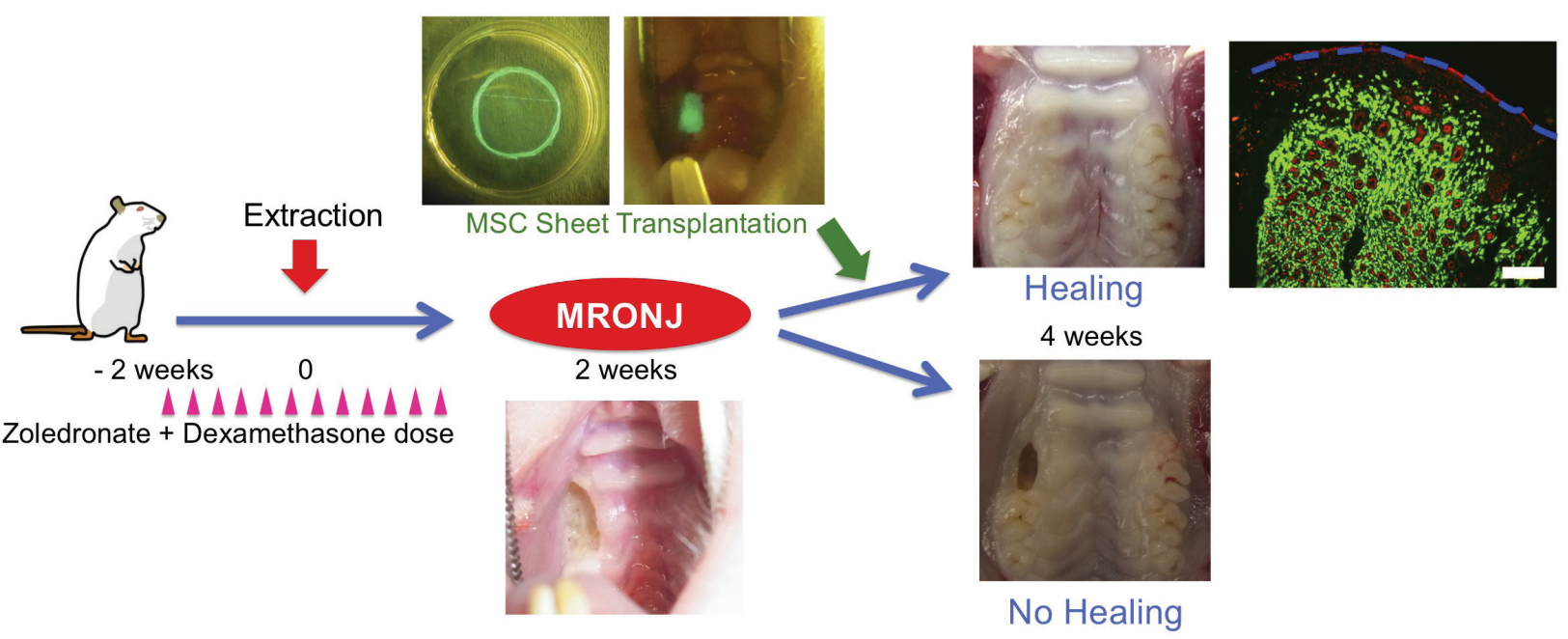

Fig. 2. Multipotent MSC sheets derived from the bone marrow of EGFP-positive SD rats, allogeneically transplanted in rat models with MRONJ-like lesions. MSC sheets were implanted in model rats with simulated medication-related osteonecrosis of the jaw MRONJ-like condition, and their efficacy in the treatment of MRONJ was examined. Normal healing was observed in the transplantation group. In addition, the transplanted EGFP-positive MSCs remained at the transplanted site stimulating the formation of new blood vessels. Scale bar $=200 \mu \mathrm{m}$. 


\section{Conclusion}

MRONJ may not occur commonly. However, several cases are not cured by conventional treatments. Thus, the management of MRONJ is a challenge in clinical practice. Though various novel methods have been investigated, no definite treatment modality has been determined. Among these, cell therapy seems to hold a promising future.

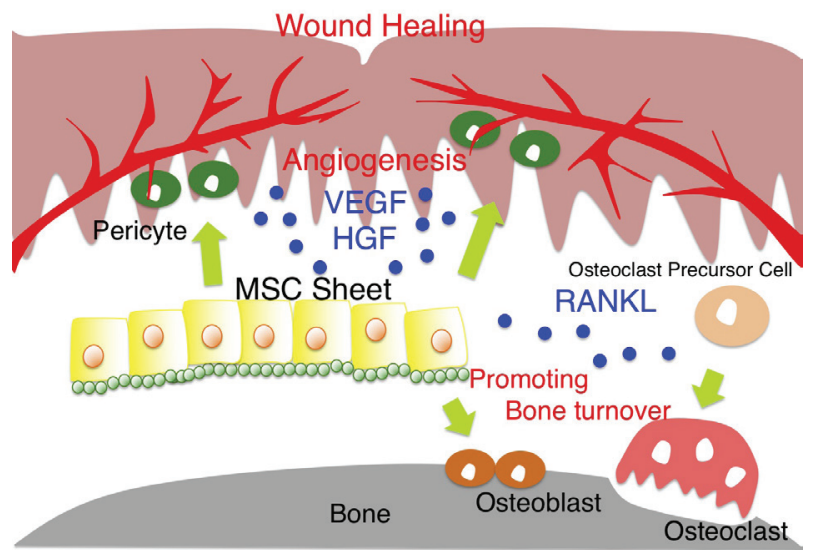

Fig. 3. Suggested effects of MSC sheets in MRONJ. The therapeutic effects of MSC sheets in medicationrelated osteonecrosis of the jaw could be due to a combination of paracrine effects such as secretion of vascular endothelial growth factor (VEGF) and hepatocyte growth factor (HGF), promotion of angiogenesis by differentiation of MSCs into pericytes, and promotion of osteoclast differentiation by antiRANKL secretion and osteoblast differentiation by MSCs themselves.

\section{Acknowledgments}

The authors declare no conflicts of interest. We would like to thank Editage (www.editage.com) for English language editing. This study was financially supported by the Creation of Innovation Centers for Advanced Interdisciplinary Research Areas Program of the Project for Developing Innovation Systems "Cell Sheet Tissue Engineering Center (CSTEC)," funded by the Ministry of Education, Culture, Sports, Science, and Technology (MEXT) of Japan, and a bilateral research project between Japan and Korea funded by the Japan Society for the Promotion of Science (JSPS), Grant number 14544639. This work was partially supported by JSPS KAKENHI, Grant numbers 18K17181 and 15K11224. NK compiled the literature review, composed the figures, and wrote the manuscript. TI edited and revised the manuscript and checked the accuracy of the data. TO, YK, and MY critically revised the manuscript.

\section{References}

Adornato MC, Morcos I, Rozanski J (2007) The treatment of bisphosphonate-associated osteonecrosis of the jaws with bone resection and autologous platelet-derived growth factors. J Am Dent Assoc 138: 971-977.

Barba-Recreo P, Del Castillo Pardo de Vera JL, Georgiev-Hristov T, Ruiz Bravo-Burguillos E, Abarrategi A, Burgueño M, García-Arranz M (2015) Adipose-derived stem cells and platelet-rich plasma for preventive treatment of bisphosphonaterelated osteonecrosis of the jaw in a murine model. J Craniomaxillofac Surg 43: 1161-1168.
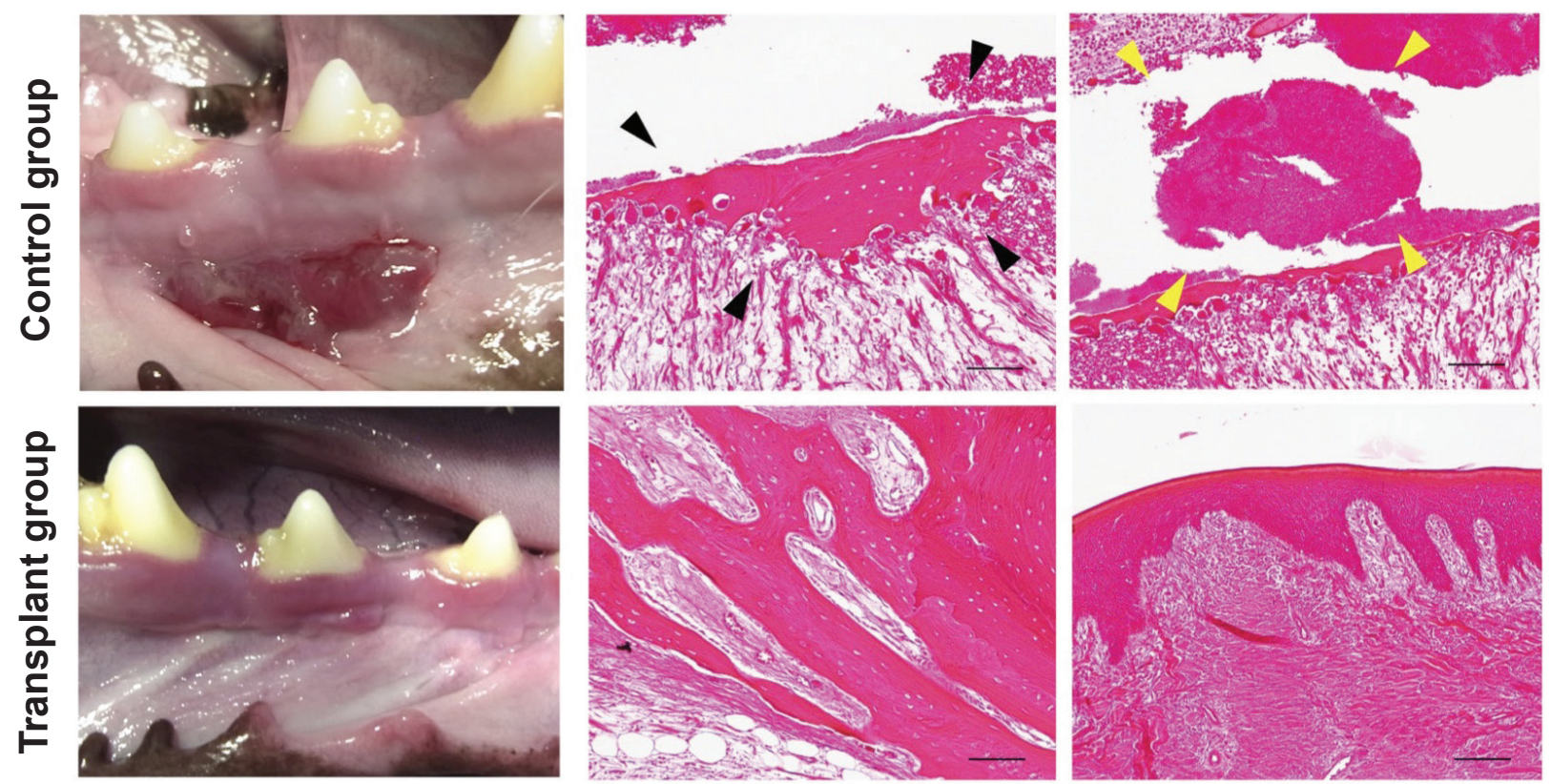

Fig. 4. MSC sheets transplantation in dog models with MRONJ-like lesions. The control group showed medication-related osteonecrosis of the jaw-like inflammatory findings and presence of sequestrum (black arrow) and bacterial colonies (yellow arrow), whereas the MSC sheet transplant group showed complete healing. Scale bar $=100 \mu \mathrm{m}$. 
Bouland C, Meuleman N, Widelec J, KeianiMothlagh K, Voisin C, Lagneaux L, Philippart P (2020) Case reports of medication-related osteonecrosis of the jaw (MRONJ) treated with uncultured stromal vascular fraction and L-PRF. J Stomatol Oral Maxillofac Surg S2468-7855(20)30144-0. DOI: 10.1016/j.jormas.2020.05.024.

Cella L, Oppici A, Arbasi M, Moretto M, Piepoli M, Vallisa D, Zangrandi A, Di Nunzio C, Cavanna L (2011) Autologous bone marrow stem cell intralesional transplantation repairing bisphosphonate related osteonecrosis of the jaw. Head Face Med 17: 16. DOI: 10.1186/1746-160X-7-16.

Cheung A, Seeman E (2010) Teriparatide therapy for alendronate-associated osteonecrosis of the jaw. N Engl J Med 363: 2473-2474.

Coleman R, Woodward E, Brown J, Cameron D, Bell R, Dodwell D, Keane M, Gil M, Davies C, Burkinshaw R, Houston SJ, Grieve RJ, Barrett-Lee PJ, Thorpe H (2011) Safety of zoledronic acid and incidence of osteonecrosis of the jaw (ONJ) during adjuvant therapy in a randomised phase III trial (AZURE: BIG 01- 04) for women with stage II/III breast cancer. Breast Cancer Res Treat 127: 429-438.

Curi MM, Cossolin GS, Koga DH, Zardetto C, Christianini S, Feher O, Cardoso CL, dos Santos MO (2011) Bisphosphonate-related osteonecrosis of the jaws - an initial case series report of treatment combining partial bone resection and autologous platelet-rich plasma. J Oral Maxillofac Surg 69: 24652472.

De Santis GC, de Macedo LD, Orellana MD, Innocentini LMAR, Ferrari TC, Ricz HMA, Caruso SR, Fernandes TR, Covas DT (2020) Mesenchymal stromal cells administration for osteonecrosis of the jaw caused by bisphosphonate: report of two cases. Acta Oncol 59: 789-792.

De Souza Tolentino E, de Castro TF, Michellon FC, Passoni ACC, Ortega LJA, Iwaki LCV, da Silva MC (2019) Adjuvant therapies in the management of medication-related osteonecrosis of the jaws: systematic review. Head Neck 41: 4209-4228.

Favia G, Tempesta A, Limongelli L, Crincoli V, Maiorano E (2018) Medication-related osteonecrosis of the jaw: surgical or non-surgical treatment? Oral Dis 24: 238-242.

Fleissig Y, Regev E, Lehman H (2012) Sunitinib related osteonecrosis of jaw: a case report. Oral Surg Oral Med Oral Pathol Oral Radiol 113: e1-e3.

Fliefel R, Tröltzsch M, Kühnisch J, Ehrenfeld M, Otto S (2015) Treatment strategies and outcome of bisphosphonate-related osteonecrosis of the jaw (BRONJ) with characterization of patients: a systematic review. Int J Oral Maxillofac Surg 44: 568585.

Freiberger JJ, Padilla-Burgos R, McGraw T, Suliman HB, Kraft KH, Stolp BW, Moon RE, CPiantadosi CA (2012) What is the role of hyperbaric oxygen in the management of bisphosphonate-related osteonecrosis of the jaw: a randomized controlled trial of hyperbaric oxygen as an adjunct to surgery and antibiotics. J Oral Maxillofac Surg 70: 1573-1583.

Gonzálvez-García M, Rodríguez-Lozano FJ, Villanueva V, Segarra-Fenoll D, Rodríguez-González MA, Oñate-Sánchez R, Blanquer M, Moraleda JM (2013) Cell therapy in bisphosphonate-related osteonecrosis of the jaw. J Craniofac Surg 24: e226-e228.

Gryseleyn R, Maes JM, Ferri J (2016) Osteochemonecrosis after mandible reconstruction. N Engl J Med 374: 1097-1098.

Hayashida S, Soutome S, Yanamoto S, Fujita S, Hasegawa T, Komori T, Kojima Y, Miyamoto H, Shibuya Y, Ueda N, Kirita T, Nakahara H, Shinohara M, Umeda M (2017) Evaluation of the treatment strategies for medication-related osteonecrosis of the jaws (MRONJ) and the factors affecting treatment outcome: a multicenter retrospective study with propensity score matching analysis. J Bone Miner Res 32: 2022-2029.

Hayashida S, Yanamoto S, Fujita S, Hasegawa T, Komori T, Kojima Y, Miyamoto H, Shibuya Y, Ueda N, Kirita T, Nakahara H, Shinohara M, Kondo E, Kurita H, Umeda M (2020) Drug holiday clinical relevance verification for antiresorptive agents in medicationrelated osteonecrosis cases of the jaw. J Bone Miner Metab 38: 126-134.

Heifetz-Li JJ, Abdelsamie S, Campbell CB, Roth S, Fielding AF, Mulligan JP (2019) Systematic review of the use of pentoxifylline and tocopherol for the treatment of medication-related osteonecrosis of the jaw. Oral Surg Oral Med Oral Pathol Oral Radiol 128: 491-497.

Hinson AM, Siegel ER, Stack BC (2015) Temporal correlation between bisphosphonate termination and symptom resolution in osteonecrosis of the jaw: a pooled case report analysis. J Oral Maxillofac Surg 73: 53-62

Hokugo A, Kanayama K, Sun S, Morinaga K, Sun Y, Wu QQ, Sasaki H, Okawa H, Evans C, Ebetino FH, Lundy MW, Sadrerafi K, McKenna CE, Nishimura I (2019) Rescue bisphosphonate treatment of alveolar bone improves extraction socket healing and reduces osteonecrosis in zoledronate-treated mice. Bone 123: $115-128$.

Iwata $\mathrm{T}$, Yamato $\mathrm{M}$, Washio $\mathrm{K}$, Yoshida $\mathrm{T}$, Tsumanuma Y, Yamada A, Onizuka S, Izumi Y, Ando T, Okano T, Ishikawa I (2018) Periodontal regeneration with autologous periodontal ligamentderived cell sheets - A safety and efficacy study in ten patients. Regen Ther 9: 38-44.

Kaibuchi N, Iwata T, Onizuka S, Yano K, Tsumanuma Y, Yamato M, Okano T, Ando T (2019) Allogeneic multipotent mesenchymal stromal cell sheet transplantation promotes healthy healing of wounds caused by zoledronate and dexamethasone in canine mandibular bones. Regen Ther 10: 77-83.

Kaibuchi N, Iwata T, Yamato M, Okano T, Ando $\mathrm{T}$ (2016) Multipotent mesenchymal stromal cell sheet therapy for bisphosphonate-related osteonecrosis of the jaw in a rat model. Acta Biomater 42: 400-410. 
Khan AA, Morrison A, Hanley DA, Felsenberg D, McCauley LK, O'Ryan F, Reid IR, Ruggiero SL, Taguchi A, Tetradis S, Watts NB, Brandi ML, Peters E, Guise T, Eastell R, Cheung AM, Morin SN, Masri B, Cooper C, Morgan SL, ObermayerPietsch B, Langdahl BL, Al Dabagh R, Davison KS, Kendler DL, Sándor GK, Josse RG, Bhandari M, El Rabbany M, Pierroz DD, Sulimani R, Saunders DP, Brown JP, Compston J, International Task Force on Osteonecrosis of the Jaw (2014) Diagnosis and management of osteonecrosis of the jaw: a systematic review and international consensus. J Bone Miner Res 30: 3-23.

Kikuiri T, Kim I, Yamaza T, Akiyama K, Zhang Q, Li Y, Chen C, Chen W, Wang S, Le AD, Shi S (2010) Cell-based immunotherapy with mesenchymal stem cells cures bisphosphonate-related osteonecrosis of the jaw-like disease in mice. J Bone Miner Res 25: 1668-1679.

Kuroshima S, Nakajima K, Sasaki M, Takashi I, Sumita Y, Asahara T, Asahina I, Sawase T (2019) Systemic administration of quality- and quantitycontrolled PBMNCs reduces bisphosphonate-related osteonecrosis of jaw-like lesions in mice. Stem Cell Res Ther 10: 209. DOI: 10.1186/s13287-019-1308-8.

Kuroshima S, Sasaki M, Nakajima K, Tamaki S, Hayano H, Sawase T (2018) Transplantation of noncultured stromal vascular fraction cells of adipose tissue ameliorates osteonecrosis of the jaw-like lesions in mice. J Bone Miner Res 33: 154-166.

Li Y, Xu J, Mao L, Liu Y, Gao R, Zheng Z, Chen W, Le A, Shi S, Wang S (2013) Allogeneic mesenchymal stem cell therapy for bisphosphonate-related jaw osteonecrosis in swine. Stem Cells Dev 22: 2047-2056.

Lo JC, O'Ryan FS, Gordon NP, Yang J, Hui RL, Martin D, Hutchinson M, Lathon PV, Sanchez G, Silver P, Chandra M, McCloskey CA, Staffa JA, Willy M, Selby JV, Go AS, Predicting Risk of Osteonecrosis of the Jaw with Oral Bisphosphonate Exposure (PROBE) Investigators (2010) Prevalence of osteonecrosis of the jaw in patients with oral bisphosphonate exposure. J Oral Maxillofac Surg 68: 243-253.

Magopoulos C, Karakinaris G, Telioudis Z, Vahtsevanos K, Dimi- trakopoulos I, Antoniadis K, Delaroudis S (2007) Osteonecrosis of the jaws due to bisphosphonate use. A review of 60 cases and treatment proposals. Am J Otolaryngol 28: 158-163.

Maluf G, Caldas RJ, Fregnani ER, da Silva Santos PS (2019) A rare case of bevacizumab-related osteonecrosis of the jaw associated with dental implants. Int J Implant Dent 5: 34. DOI: 10.1186/ s40729-019-0188-0.

Marx RE (2003) Pamidronate (Aredia) and zoledronate (Zometa) induced avascular necrosis of the jaws: a growing epidemic. J Oral Maxillofac Surg 61: 1115-1117.

Miyahara Y, Nagaya N, Kataoka M, Yanagawa B, Tanaka K, Hao H, Ishino K, Ishida H, Shimizu T, Kangawa K, Sano S, Okano T, Kitamura S, Mori H (2006) Monolayered mesenchymal stem cells repair scarred myocardium after myocardial infarction. Nat Med 12: 459-465.

Mozzati M, Gallesio G, Arata V, Pol R, Scoletta M (2012) Platelet-rich therapies in the treatment of intravenous bisphosphonate-related osteonecrosis of the jaw: a report of 32 cases. Oral Oncol 48: 469-474.

Nishida N, Yamato M, Hayashida Y, Watanabe K, Yamamoto K, Adachi E, Nagai S, Kikuchi A, Maeda N, Watanabe H, Okano T, Tano Y (2004) Corneal reconstruction with tissue-engineered cell sheets composed of autologous oral mucosal epithelium. N Engl J Med 351: 1187-1196.

Ogata K, Katagiri W, Osugi M, Kawai T, Sugimura Y, Hibi H, Nakamura S, Ueda M (2015) Evaluation of the therapeutic effects of conditioned media from mesenchymal stem cells in a rat bisphosphonaterelated osteonecrosis of the jaw-like model. Bone 74: 95-105.

Ohki T, Yamato M, Ota M, Takagi R, Murakami D, Kondo M, Sasaki R, Namiki H, Okano T, Yamamoto M (2012) Prevention of esophageal stricture after endoscopic submucosal dissection using tissueengineered cell sheets. Gastroenterology 143: 582-588.

Pageau SC (2009) Denosumab. MAbs 1: 210-215.

Park JH, Kim JW, Kim SJ (2017) Does the addition of bone morphogenetic protein 2 to platelet-rich fibrin improve healing after treatment for medicationrelated osteonecrosis of the jaw? J Oral Maxillofac Surg 75: 1176-1184.

Rodríguez-Lozano FJ, Oñate-Sánchez R, Gonzálvez-García M, Vallés-Bergadá M, Martínez CM, Revilla-Nuin B, Guerrero-Gironés J, Moraleda JM, García-Bernal D (2020) Allogeneic bone marrow mesenchymal stem cell transplantation in tooth extractions sites ameliorates the incidence of osteonecrotic jaw-like lesions in zoledronic acidtreated rats. J Clin Med 9: 1649. DOI: 10.3390/ jcm9061649.

Ruggiero SL, Dodson TB, Fantasia J, Goodday R, Aghaloo T, Mehrotra B, O'Ryan F, American Association of Oral and Maxillofacial Surgeons (2014) American Association of Oral and Maxillofacial Surgeons position paper on medication-related osteonecrosis of the jaw - 2014 update. J Oral Maxillofac Surg 72: 1938-1956.

Rupel K, Ottaviani G, Gobbo M, Contardo L, Tirelli G, Vescovi P, Di Lenarda R, Biasotto M (2014) A systematic review of therapeutical approaches in bisphosphonates-related osteonecrosis of the jaw (BRONJ). Oral Oncol 50: 1049-1057.

Scoletta M, Arduino PG, Reggio L, Dalmasso P, Mozzati M (2010) Effect of low-level laser irradiation on bisphosphonate-induced osteonecrosis of the jaws: pre liminary results of a prospective study. Photomed Laser Surg 28: 179-184.

Sim IW, Borromeo GL, Tsao C, Hardiman R, Hofman MS, Papatziamos Hjelle C, Siddique M, Cook GJR, Seymour JF, Ebeling PR (2020) Teriparatide promotes bone healing in medication-related osteonecrosis of the jaw: a placebo-controlled, randomized trial. J Clin Oncol 38: 2971-2980. 
Voss PJ, Matsumoto A, Alvarado E, Schmelzeisen R, Duttenhöfer F, Poxleitner P (2017) Treatment of stage II medication-related osteonecrosis of the jaw with necrosectomy and autologous bone marrow mesenchymal stem cells. Odontology 105: 484-493.

Zang X, He L, Zhao L, He Y, Xiao E, Zhang Y (2019) Adipose-derived stem cells prevent the onset of bisphosphonate-related osteonecrosis of the jaw through transforming growth factor $\beta$-1-mediated gingival wound healing. Stem Cell Res Ther 10: 169. DOI: 10.1186/s13287-019-1277-y.

\section{Discussion with Reviewer}

Piefrancesco Pagella: What do the authors think could be a game-changing approach in cell-therapy approaches for MRONJ? Do they think it is simply about the choice of the "right" cells, or might there be other parameters to keep into consideration?

Authors: Currently, the only solution for dealing with necrotic bone is removal. However, cell therapy can be a game-changing approach that can even regenerate necrotic bone.

Editor's note: The Scientific Editor responsible for this paper was Thimios Mitsiadis. 